MAY 2018

VOLUME 9 PART 2
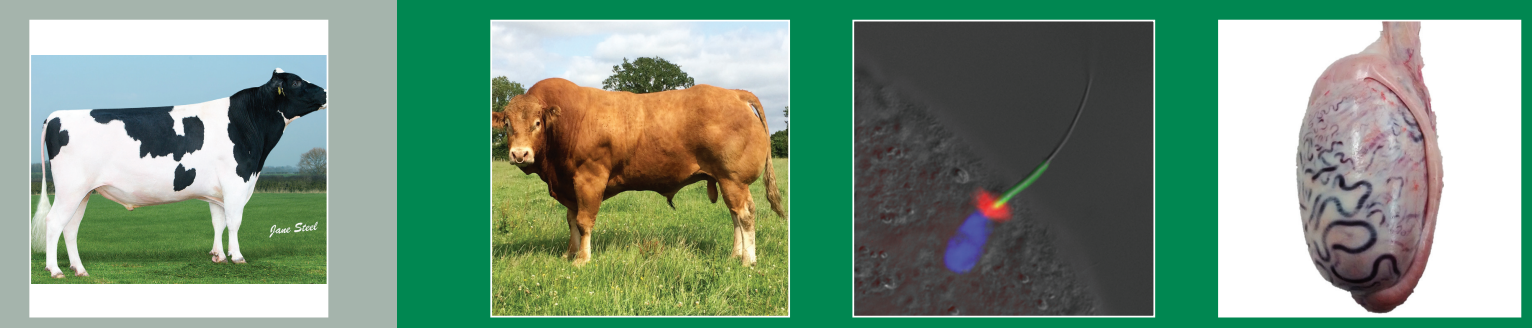

Advances in Animal Biosciences

\title{
Theory to Practice
}

Proceedings of the International Bull Fertility Conference,

27-30 May 2018, Westport, Ireland 


\title{
Advances in Animal Biosciences
}

\section{Management Board}

Nigel Scollan (chair), Bruce Beveridge, Christopher Knight, Howard Simmins (BSAS); Philippe Chemineau, Matthias Gauly, Andrea Rosati (EAAP); Nicolas Friggens, Stephane Ingrand, Jaap Van Milgen (INRA)

\section{Editor-in-Chief \\ Cledwyn Thomas}

\begin{abstract}
Aims and Scope
Advances in Animal Biosciences is an associated publication to the journal animal. It aims to publish high-quality conference, symposium and workshop proceedings about animal-related aspects of the life sciences with emphasis on farmed and other managed animals. These can be in the form of a book of abstracts, summaries or complete papers. The format will highlight the title of the meeting and organisations involved but the publications will have the added advantage of forming a series under Advances in Animal Biosciences.

Subject areas can include aspects of Breeding and Genetics, Nutrition, Physiology and Functional Biology of Systems, Behaviour, Health and Welfare, Livestock Farming Systems, Human Health and Product Quality.

However, due to the integrative nature of biological systems, monographs and conference proceedings dealing with the translation of basic and strategic science into the whole animal and farming system and the impact on Productivity, Product Quality, Food Security, the Environment, Climate Change and Humans will be particularly welcome.
\end{abstract}

\section{Information for Conference Organisers}

The Animal Consortium together with Cambridge University Press offers conference organisers a package that enables publication of high-quality conference, symposium and workshop proceedings about animal-related aspects of the life sciences with emphasis on farmed and other managed animals.

Summaries, abstracts or full papers may be published in Advances in Animal Biosciences and high-quality invited papers from these meetings may be submitted and published as a defined series in animal.

Conference organizers interested in publishing their proceedings should send an outline proposal for publication in Advances in Animal Biosciences, animal, or both journals to cko@cambridge.org. The publisher together with the Editors-in-Chief will then provide an estimate of costs and the procedures to be used.

Manuscripts submitted to Advances in Animal Biosciences will be reviewed by the Editor-in-Chief and papers submitted to animal will be peer reviewed. If accepted after review, proceedings will be published within 12 weeks of receipt by the Publisher.

\section{Cover images}

Holstein Bull courtesy of B. Eivers, National Cattle Breeding Centre, Ireland.

Limousin Bull courtesy of M. McDonald, University College Dublin, Ireland.

Bull Sperm courtesy of P. Sutovsky, University of Missouri, USA.

Bull Testis courtesy of B. Fernandez-Fuertes, University College Dublin, Ireland. 


\section{Proceedings}

\section{Theory to Practice}

International Bull Fertility Conference

Castlecourt Hotel, Westport, Mayo, Ireland

27 - 30 May 2018

\section{Advances in Animal Biosciences}

This book is part of a series which is a companion to the journal ANIMAL

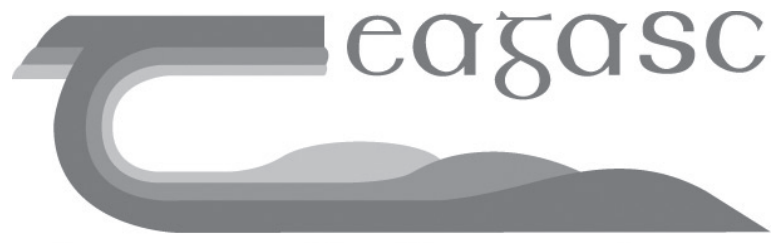

Agriculture and Food Development Authority
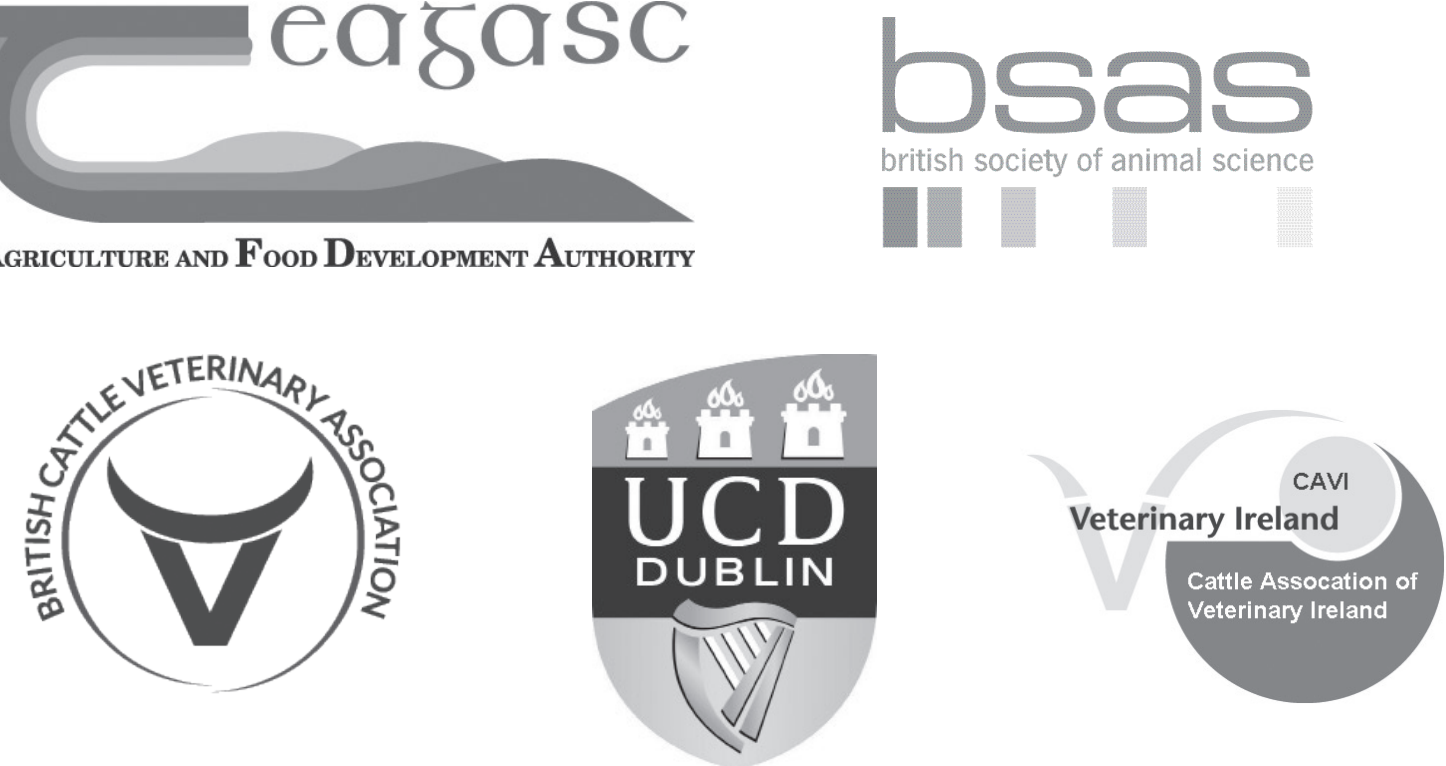

UNIVERSITY of LIMERICK

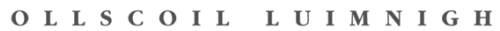

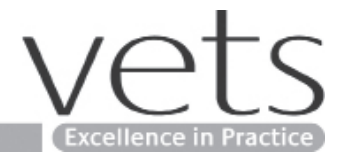


'Bull Fertility, Theory to Practice' follows on from the hugely successful International Conference on Cow Fertility held in May 2014, the proceedings of which were published in Animal, Vol 8 Issue S1 May 2014 (see http://bit.ly/2sT6a8X).

Over the past 80 years most bovine reproductive physiology research has focused on ways to improve cow fertility. Less emphasis has been placed on male fertility and few meetings specifically dedicated to the specific subject of bull fertility have taken place; this conference aims to fill that gap. The conference aspires to be a 'one-stop shop' for academics, industry professionals and veterinary practitioners with an interest in bull fertility. The breath of the conference extends from basic new knowledge / technologies to the field application of this knowledge / technologies - hence the sub-title Theory to Practice. Leading experts from academia, veterinary practice and industry from around the globe will discuss the significant developments and challenges facing bull fertility including male reproductive physiology, nutrition, puberty, to the way genomicallyassisted selection has revolutionised dairy cattle breeding and the role for sexed semen.

Views expressed in all contributions are those of the authors and not those of the society or partners. The full reviews of invited contributions are published in Animal, ANM 12.S1 cambridge.org/animal

\section{Editors}

M G Diskin

S Fair

D A Kenny

P Lonergan 


\section{Theory to Practice Bull Fertility}

$\begin{array}{lc} & \text { PAGE } \\ \text { Contents } & \text { i-iv } \\ \text { Invited oral presentations } & 279-297 \\ \text { Submitted oral and poster presentations } & 298-335 \\ \text { Author Index } & \text { I }\end{array}$




\section{Contents}

\section{Setting the Scene}

279 Historical and futuristic developments in bovine semen technology

P Lonergan

\section{Male Reproductive Physiology}

280 Ontology and endocrinology of the reproductive system of bulls from fetus to maturity M McGowan, M K Holland and G Boe-Hansen

281 Spermatogenesis in the bull

C Staub, L Johnson

282 The effect of nutrition on timing of pubertal onset and subsequent fertility in the bull

D A Kenny, C J Byrne

\section{BULL FERTILITY}

283 Using artificial insemination vs natural service in beef herds

P S Baruselli, R M Ferreira, M F Sá Filho, G A Bó

284 Understanding the causes of variation in reproductive wastage among bulls

S Fair, P Lonergan

285 Integrating a semen quality control program and sire fertility at a large artificial insemination organization B R Harstine, M D Utt, J M DeJarnette

\section{Optimising Semen Procedures and Sexed Semen}

286 Semen handling, time of insemination and insemination technique in cattle M G Diskin

287 Semen Sexing: current state of the art with emphasis on bovine species R Vishwanath, J F Moreno

288 Applications and benefits of sexed semen in dairy and beef herds S A Holden, S T Butler

\section{Sperm and Seminal Plasma}

289 The potential of seminal fluid mediated paternal-maternal communication to optimise pregnancy success J J Bromfield

290 The epic journey of sperm through the female reproductive tract D J Miller

291 Sperm-oocyte interactions and their implications for bull fertility, with emphasis on the ubiquitin-proteas system

P Sutovsky 


\section{Thermoregulation AND BeHAVIOUR}

292 Testicular vascular cone development and its association with scrotal thermoregulation, semen quality and sperm production in bulls

J P Kastelic, G Rizzoto, J Thundathil

293 Principles of maximizing bull semen production at genetic centers

J L Schenk

\section{Pathophysiology of Bull Subfertility}

294 Abnormalities of the bull: occurrence, diagnosis and treatment of abnormalities of the bull, including structural soundness

D F Wolfe

295 The use of bull breeding soundness evaluation to identify subfertile and infertile bulls

A D Barth

296 Risks of disease transmission through semen in cattle M D Givens

\section{DNA TEChNOLOGIES}

297 Genomics of bull fertility

J F Taylor, R D Schnabel, P Sutovsky

\section{Submitted Presentations - ORals ANd POSTers}

298 Testicular biometry and hemodynamic of the testicular artery by Doppler ultrasonography in Braford bulls from 12 to 24 months of age

L A Claus, G Pereira, F Barca Jr, P Favaro, I Dias, C H Bofinger, E L Ribeiro, C Koetz Jr

299 The use of collar accelerometers to investigate the activity of dairy natural service bulls R Waite, C Dwyer, D Beggs, P Mansell, M Stevenson, J Hills, M Pyman

$300 \quad$ Bull sperm sncRNAs: A new source for potential fertility biomarkers?

E Sellem, S Marthey, H Kiefer, C Le Danvic, A Allais-Bonnet, L Jouneau, A Rau, H Jammes, L Schibler

301 Effects of copper and zinc supplementation on standard and novel measures of fertility in peripubertal beef bulls

T Geary, R Waterman, M Van Emon, A Zezeski, J Heldt, J Spears

302 Objective analysis of frozen bovine semen using CASA and flow cytometry M Spilman, K Burton, J Statham

303 A descriptive analysis of bull sperm methylome using reduced representation bisulphite sequencing (RRBS) J-P Perrier, E Sellem, A Prézelin, M Gasselin, L Jouneau, F Piumi, H Al Adhami, M Weber, S Fritz, D Boichard, C Le Danvic, L Schibler, H Jammes, H Kiefer

304 The relation between the functional status and miRNA profile of cryopreserved bovine semen E Malama, S Bauersachs, M Siuda, F Janett, H Bollwein

305 Natural service bulls in Australian pasture-based dairy herds: management practices, breeding soundness evaluations, and risk factors associated with pre- and post-mating breeding soundness A Hancock, P Younis, D Beggs, P Mansell, M Pyman

306 The genetic background of three fertility disorders in Nordic red cattle breeds M Andersson, H Venhoranta, T Iso-Touru, K Flisikowski, C Wurmser, H Pausch 
308 Hemodynamics evaluation of the supratesticular artery in bulls in the different seasons of the year P Favaro, G Pereira, F Barca Jr, E M Franco, M Seneda, C Koetz Jr

309 Overview of bull fertility in traditional systems of beef production in Southern Spain J M Sánchez, L M Rosales, L Quevedo, C C Perez-Marin

310 Relationship between scrotal circumference and body weight in pasture raised Jersey and Holstein bulls R Waite, C Dwyer, D Beggs, P Mansell, M Stevenson, M Pyman

311 Predicting semen characteristics in Holstein and Jersey natural service sires using classification and regression tree analysis.

R Waite, C Dwyer, D Beggs, P Mansell, M Stevenson, M Pyman

312 Relationship between the echotexture of testicular parenchyma and the quality of spermatogenesis in bulls A Echegaray, S Aventín, I Muñoz, S Marcantonio, N Escartín, G Gnemmi

313 Effects of sperm selection by discontinuous Percoll@ gradient with reduced volume and centrifugation force on sperm oxidative status of thawed bull semen

L de Cássia Bicudo, A F P Siqueira, L S Castro, V S C Pinto, C M Mendes, J D Losano,

D de Souza R Angrimani, I J Fernández, M Nichi, J A Visintin, M E O A Assumpção

314 Non-infectious progressive proximal post-testicular obstruction (PPPTO) in two half-sibling AI bulls - work in progress

S Björkman, T Iso-Touru, O Peltoniemi, M Andersson

315 The effect of natural heat stress on bull semen quality and subsequent embryo development N Llamas Luceño, D Angrimani, L Bicudo, K Demeyere, B Leemans, E Meyer, A Van Soom

316 Droplet digital PCR provides robust, reproducible quantitation of sex skewed bovine semen N Cray, M Wagner, J Hauer, E Roti Roti

317 Polyunsaturated fatty acids influence offspring sex ratio in cows

W F A Marei, W A Khalil, A P G Pushpakumara, M A El-Harairy, A M A Abo El-Atta, D C Wathes,

A A Fouladi-Nashta

318 Novel portable quantitative assessment of semen motility

V Martinez, A Jepson, J Statham, M Spilman, K Burton, J Arlt, T Wood, W Poon

319 Interest in the study of the echotexture of the testicular parenchyma to evaluate the maturity of young bulls

G Gnemmi, C Maraboli, N Escartín, I Muñoz, S Marcantonio, A Echegaray

320 Advances in the proteome of electroejaculated seminal plasma from tropical-adapted bulls

N Satake, H Skovsgaard Pedersen, M McGowan, G Brandt Boe-Hansen

321 Effect of season of collection in cryopreserved semen from the Spanish native cattle breed "Asturiana de la Montaña"

C Hidalgo, J N Caamaño, C Fueyo, C Tamargo, A Salman, Á Fernández, M J Merino, M Carbajo,

F Martínez-Pastor

Title: Artificial insemination using two different AI-sheaths for training of AI in the cow in veterinary medicine J Parlevliet 
325 Relationships between the content of seminal plasma proteins and bull fertility

J M Morrell, S Resjö, J Willfors, T Hallap, F Levander, E Andreasson, D-J de Koning, P Humblot

326 Seminal plasma of AI-bulls stimulates cytokine production by bovine endometrial epithelial cells in culture in a fertility-dependent manner

T Nongbua, Y Guo, P Humblot, M Rubér, H Rodriguz-Martinez, T Ntallaris, J M Morrell

327 Is there value in doing Bull Breeding Soundness Evaluation in a first-opinion veterinary practice? M Tomlinson, PWood, A Macrae, M Mihm-Carmichael

328 Characterization of bull fertility through multicolour flow cytometric analysis of cryopreserved sperm E Malama, K Bucher, M Siuda, F Janett, H Bollwein

329 Sperm motility, semen production efficiency and field fertility in different aged Norwegian Red bulls A Khezri, B Narud, J Mbuma, F D Myromslien, E Kommisrud

330 Is genomic selection challenging the production?

K Kupisiewicz, S Borchersen

331 Sperm DNA fragmentation and kinetics of development of bovine embryos produced in vitro using bulls of different field fertility

C Maicas, C Passaro, C J Byrne, S T Butler, P Lonergan

$332 \quad$ Nuclear protein contents - An epigenetic marking of sperm cells

C Le Danvic, F Bray, E Sellem, H Kiefer, H James, C Rolando, L Schibler

333 Effect of altering plane of nutrition during the first and second six months of life on in-vitro fertilizing ability and DNA fragmentation in mature Holstein-Friesian bulls

C J Byrne, B Fernandez-Fuertes, S Fair, C Maicas, P Lonergan, D A Kenny

334 Progesterone induces the release of bovine sperm from oviductal epithelial cells J Romero-Aguirregomezcorta, S Cronin, S Fair

335 Variation in the field fertility of dairy bulls used in AI

E M Donnellan, M M Kelleher, S Fair 